\title{
Response of seeds and pollen of Onobrychis viciifolia and Onobrychis oxyodonta var. armena to $\mathrm{NaCl}$ stress
}

\author{
Ramazan Beyaz ${ }^{1}$, Gamze Kaya ${ }^{2 *}$, Sati Cocu³ ${ }^{3}$ Cengiz Sancak ${ }^{4}$ \\ ${ }^{1}$ Ankara University/Institute of Biotechnology - Dept. of Basic Biotechnology, Ankara - Turkey. \\ ${ }_{3}^{2}$ Central Research Institute for Field Crops - Dept. of Genetic Resources, PK 226, Ulus, Ankara - Turkey. \\ ${ }^{3}$ Erciyes University/Faculty of Agriculture - Dept. of Field Crops, Kayseri - Turkey. \\ ${ }^{4}$ Ankara University/Faculty of Agriculture - Dept. of Field Crops, Ankara - Turkey. \\ *Corresponding author <pascalcik@hotmail.com> \\ Edited by: Edmilson José Ambrosano
}

\begin{abstract}
Sainfoin (Onobrychis viciifolia Scop.) is an important forage legume crop with 52 species adapted to dry and poor soils in Turkey, but little is known about the effects of salinity on germination and seedling growth in arid and semiarid regions suffering from salinity problem. The seeds and pollen of two species of sainfoin O. viciifolia and O. oxyodonta var. armena (Syn: O. armena) were exposed to 0, 5, 10, 20 and $30 \mathrm{dS} \mathrm{m}^{-1}$ of $\mathrm{NaCl}$ under in vivo and in vitro conditions and evaluated for germination under salt stress by comparing germination percentage, mean germination time, root and shoot length, fresh and dry seedling weight and dry matter. Increased salinity levels generally resulted in decrease in all traits except time to germination, dry seedling weight and dry matter, which increased at high salinity levels. O. viciifolia seeds germinated and grew more rapidly compared to O. armena seeds under $\mathrm{NaCl}$ stress. No decrease in germination and seedling growth up to $10 \mathrm{dS} \mathrm{m}^{-1}$ was recorded. On the other hand, there was a clear difference for germination and seedling growth between in vivo and in vitro conditions. Lower values were obtained from in vitro experiments; suggesting that mineral salts, sucrose and agar may have resulted in higher osmotic potential inhibiting germination and seedling growth of species compared invivo conditions. Decrease in pollen germination with increasing salinities was very sharp, indicating that pollen germination had higher sensitive to salinity. But, pollen grains of O. armena germinated rapidly compared to O. viciifolia. The results emphasize that in vivo experiments could be used for screening of $\mathrm{NaCl}$ tolerance in sainfoin cultivars without expensive chemicals and sophisticated equipments, but pollen germination is more appropriate for its wild relatives.
\end{abstract}

Key words: in vivo, in vitro, sainfoin, salinity, germination

\section{Introduction}

A total of 160 Onobrychis species exists throughout the world and are spread from Baltic States to Mediterranean region passing through all region lying in the Asia and IranSiberian element. In total 27 Onobrychis species are endemic to Turkey. Sainfoin (Onobrychis viciifolia Scop.) is a perennial forage legume crop which is widely adapted to calcareous, well drained, poor and dry soils (Açiköz, 2001; Cavallarin et al., 2005). It has been grown extensively in Eastern Europe and West Asia (Sancak et al., 2003). It is highly tolerant to salinity and drought and improves soil fertility by fixing atmospheric nitrogen (Özaslan-Parlak and Parlak, 2008; Imanparast and Hassanpanah, 2009). It has erect stems and deep tap roots holding soil firmly to the deeper layer and prevents soil erosion. It is preferred to other forage plants on dry soils of Anatolia because it produces satisfactorily hay under adverse conditions (Cavallarin et al., 2005). O. oxyodonta var. armena (Syn: O. armena Boiss. and Huet) is a winter-resistant wild sainfoin species and is found extensively in meadows of Central Anatolia and Eastern Anatolia regions (Elçi, 2005).

Sainfoin is largely grown on low moisture soils of Anatolia where evaporation exceeds precipitation, resulting in salt accumulation on the soil surface (Kaya et al., 2003; Pessarakli, 1999). There are limited reports on the effects of salinity on seed germination and growth in Onobrychis species. Elçi (2005) indicated that it was suitable for salt infected soils and favorable yield could be obtained at moderate level of salinity. Greub et al. (1985) reported that sainfoin (Onobrychis viciifolia Scop.) was tolerant to $\mathrm{NaCl}$, but it ranked lower than the grasses. Özaslan-Parlak and Parlak (2008) has indicated a decrease in plant height, dry hay yield and crude protein ratio due to increased salinity in irrigation water. However, it could not be determined clearly that differences between species against salt tolerance are mainly due to genetic or morphologic factors. Therefore, this study investigated the seed and pollen germination and the seedling growth of $O$. viciifolia and $\mathrm{O}$. oxyodonta var. armena under various $\mathrm{NaCl}$ stresses using in vivo and in vitro techniques.

\section{Materials and Methods}

Seeds of O. viciifolia Scop. and O. oxyodonta var. armena (Syn: O. armena Boiss. and Huet) were collected from plants grown at same field, under similar cultural practices. Both species were tested against $\mathrm{NaCl}$ under in vivo and in vitro conditions. $\mathrm{NaCl}$ levels were adjusted as 5, 10,20 and $30 \mathrm{dS} \mathrm{m}^{-1}$ (electrical conductivities of the solutions) of $\mathrm{NaCl}$ using a conductivity meter (Model WTW Cond. 314i, Germany). Distilled water served as a control $\left(0 \mathrm{dS} \mathrm{m}^{-1}\right)$.

Four replicates of 50 seeds of each species were germinated between three rolled filter papers with $15 \mathrm{~mL}$ of respective test solutions. Seeds were treated with fungicide before planting; papers were replaced every two days to prevent salt accumulation. The rolled paper with seeds was put 
into sealed transparent plastic bags to avoid moisture loss. Seeds were allowed to germinate at $20 \pm 1{ }^{\circ} \mathrm{C}$ in the dark for 14 days.

Surface sterilization of the seeds of both Onobrychis species was done using 50\% commercial bleach for $15 \mathrm{~min}$ followed by rinsing with distilled sterile water. The surface-sterilized seeds were transferred to germination substrate containing MS medium (Murashige and Skoog, 1962), $30 \mathrm{~g} \mathrm{~L}^{-1}$ sucrose and $8 \mathrm{~g} \mathrm{~L}^{-1}$ agar supplemented with 2.72, 4.12, 11.30 and $17.22 \mathrm{~g} \mathrm{NaCl} \mathrm{L}^{-1}$ for obtaining EC values of $5,10,20$ and $30 \mathrm{dS} \mathrm{m}^{-1}$, respectively. The $\mathrm{pH}$ of medium was adjusted to 5.7 with $1 \mathrm{M} \mathrm{NaOH}$ or $\mathrm{HCl}$ before autoclaving at $121^{\circ} \mathrm{C}, 104 \mathrm{KPa}$ for $20 \mathrm{~min}$. Seeds were allowed to germinate at $20 \pm 1^{\circ} \mathrm{C}$ under white fluorescent light with $16 \mathrm{~h}$ photoperiod.

A seed was considered germinated when the emerging radicle elongated to $2 \mathrm{~mm}$. Germination percentage was recorded every $24 \mathrm{~h}$ for 14 days (ISTA, 2003). Mean germination time (MGT) was calculated following Ellis and Roberts (1980) to assess the rate of germination. MGT $=\Sigma \mathrm{Dn} / \Sigma \mathrm{D}$, where $\mathrm{n}$ is the number of the seeds newly germinated on day $\mathrm{D}$, and $\mathrm{D}$ is the number of days from the beginning. Root, shoot length, fresh and dry seedling weights were measured on the 14th day. Dry weights were measured after drying samples at $70^{\circ} \mathrm{C}$ for $48 \mathrm{~h}$ in an oven.

Media reported to germinate pollen grains of sainfoin (Onobrychis viciifolia Scop.) described by Sancak et al. (2003) had a common medium containing of $100 \mathrm{~g} \mathrm{~L}^{-1}$ sucrose, $200 \mathrm{mg} \mathrm{L}^{-1} \mathrm{KNO}_{3}, 150 \mathrm{mg} \mathrm{L}^{-1} \mathrm{MgSO}_{4}, 150 \mathrm{mg} \mathrm{L}^{-1} \mathrm{Ca}\left(\mathrm{NO}_{3}\right)_{2}$, $175 \mathrm{~g} \mathrm{~L}^{-1}$ PEG $4000,150 \mathrm{mg} \mathrm{L}^{-1} \mathrm{H}_{3} \mathrm{BO}_{3}$ and stigma extract at $\mathrm{pH}$ 6.5. Pollen was left to germinate for 1 hour at $24^{\circ} \mathrm{C}$ under cool white fluorescent light $\left(35 \mu \mathrm{mol} \mathrm{m} \mathrm{s}^{-2} \mathrm{~s}^{-1}\right)$. Germination was observed under light microscope (Olympus BH2). Pollen grains with pollen tube longer than the diameter of pollen were considered as germinated (Sancak et al., 2003).

The experimental design was two factors completely randomized design (CRD) with four replications. Data given in percentages were subjected to arcsin transformation before statistical analysis. For all investigated parameters, Analysis of Variance was performed using the MSTAT-C computer software (Michigan State University). Differences among the mean values were compared by Duncan's Multiple Range test $(p<0.05)$.

\section{Results and Discussion}

Seed germination percentage decreased by increasing $\mathrm{NaCl}$ in both species while the decrease was less in O. viciifolia compared to $O$. armena (Figure 1). The lowest germination $(40.5 \%)$ was determined in $O$. armena at $30 \mathrm{dS} \mathrm{m}$. The lower doses of $\mathrm{NaCl}$ did not change the seed germination; however, seed germination drastically declined at doses higher than $20 \mathrm{dS} \mathrm{m}^{-1}$.

Greater reduction in shoot length due to $\mathrm{NaCl}$ was very evident $(p<0.01)$ (Table 1). The longest shoots were obtained from $\mathrm{O}$. viciifolia under all $\mathrm{NaCl}$ stresses. Shoot length was severely influenced by $\mathrm{NaCl}$ while the impact was more detrimental on $\mathrm{O}$. armena. Increased $\mathrm{NaCl}$ diminished root length of the two species; however, this decrease was more prominent in O. armena.

Depending on the decrease in shoot and root length, fresh and dry seedling weights reduced gradually with the

Table 1 - Mean germination time (MGT), shoot length, root length, seedling fresh and dry weight and dry matter ratio of sainfoin species at various $\mathrm{NaCl}$ levels under in vivo conditions.

\begin{tabular}{|c|c|c|c|c|c|c|c|}
\hline Variety & $\mathrm{NaCl}$ & MGT & Shoot length & Root length & Seedling fresh weight & Seedling dry weight & Dry matter \\
\hline \multirow{6}{*}{ O. viciifolia } & $\mathrm{dS} \mathrm{m}^{-1}$ & day & \multicolumn{2}{|c|}{ 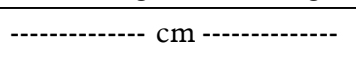 } & \multicolumn{2}{|c|}{ 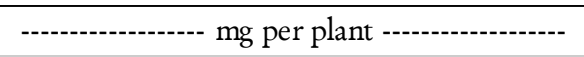 } & $\%$ \\
\hline & 0 & $1.94^{\mathrm{f}}$ & $5.69^{a}$ & 4.18 & $152^{\mathrm{a}}$ & $9.3^{\mathrm{bc}}$ & $6.0^{f}$ \\
\hline & 5 & $1.95^{\mathrm{f}}$ & $4.91^{\mathrm{b}}$ & 5.13 & $128^{\mathrm{ab}}$ & $9.8^{\mathrm{bc}}$ & $7.6^{\text {ef }}$ \\
\hline & 10 & $2.07^{f}$ & $3.25^{\mathrm{d}}$ & 3.13 & $94^{\text {bcd }}$ & $9.8^{\mathrm{bc}}$ & $9.8^{\mathrm{cd}}$ \\
\hline & 20 & $2.57^{\mathrm{de}}$ & $1.97^{\mathrm{e}}$ & 2.47 & $72^{\text {cde }}$ & $10.8^{\mathrm{b}}$ & $14.8^{\mathrm{b}}$ \\
\hline & 30 & $4.46^{\mathrm{b}}$ & $0.56^{\mathrm{f}}$ & 1.20 & $42^{\text {ef }}$ & $12.3^{\mathrm{a}}$ & $28.8^{\mathrm{a}}$ \\
\hline Mean & & 2.60 & 3.27 & $3.22 \mathrm{a}$ & 98 & 10.3 & 13.4 \\
\hline \multirow{5}{*}{$\begin{array}{l}\text { O. oxyodonta var. } \\
\text { armena }\end{array}$} & 0 & $2.33^{\mathrm{ef}}$ & $3.57^{\mathrm{cd}}$ & 4.52 & $109^{\mathrm{abc}}$ & $8.5^{\mathrm{c}}$ & $8.0^{\mathrm{de}}$ \\
\hline & 5 & $2.85^{\mathrm{d}}$ & $3.90^{\circ}$ & 4.21 & $106^{\mathrm{abc}}$ & $8.5^{\mathrm{c}}$ & $6.8^{e f}$ \\
\hline & 10 & $3.91^{\mathrm{c}}$ & $2.46^{\mathrm{e}}$ & 3.21 & $76^{\text {cde }}$ & $8.3^{c}$ & $10.5^{c}$ \\
\hline & 20 & $5.79^{a}$ & $0.66^{f}$ & 1.49 & $53^{\text {de }}$ & $9.5^{b c}$ & $15.8^{\mathrm{b}}$ \\
\hline & 30 & -8 & $-g$ & - & $-f$ & $-d$ & $-g$ \\
\hline Mean & & 2.97 & 3.48 & $2.69^{b}$ & 69 & 7.0 & 10.3 \\
\hline
\end{tabular}

Summary of ANOVA

\begin{tabular}{|c|c|c|c|c|c|c|}
\hline Variety (A) & $* *$ & $* *$ & $* *$ & $* *$ & $* \%$ & $* \%$ \\
\hline $\mathrm{NaCl}(\mathrm{B})$ & $* * *$ & $* *$ & $* \%$ & $x \%$ & $\% \%$ & $* \%$ \\
\hline$A \times B$ & $* *$ & $* *$ & ns & $*$ & $* *$ & $* *$ \\
\hline
\end{tabular}

*significant at $p<0.05, * p<0.01$ and ns: non-significant. Different letters at the same column show significant differences at 0.05 level. 
increasing salinity stress (Table 1). No seedling growth was observed in $O$. armena subjected to $30 \mathrm{dS} \mathrm{m} \mathrm{m}^{-1}$. Higher fresh seedling weights were recorded on $O$. viciifolia compared to O. armena at all $\mathrm{NaCl}$ levels. Dry Seedling weight showed a trend similar to that of fresh weight and showed decline in fresh seedling weight, dry weight enhanced with increasing $\mathrm{NaCl}$ levels. Increase in dry weight also resulted in increased dry matter of both Onobrychis species.

$\mathrm{NaCl}$ influenced seed germination of the species differently. Seed germination was not reduced at $5 \mathrm{dS} \mathrm{m}^{-1}$, while $10 \mathrm{dS} \mathrm{m}^{-1}$ caused reduction in germination (Figure 2). Furthermore, higher $\mathrm{NaCl}$ concentration resulted in lower vi- ability of the seeds. The detrimental effect of $\mathrm{NaCl}$ on seed germination appeared at $30 \mathrm{dS} \mathrm{m}^{-1}$. However, mean germination time was delayed by increased $\mathrm{NaCl}$. Apparent difference was recorded among the species. MGT increased with each increase in $\mathrm{NaCl}$ stress in the two species. Contrarily, $\mathrm{NaCl}$ level of $20 \mathrm{dS} \mathrm{m}^{-1}$ caused drastic delay in germination time of two species in general (Table 2).

For the species, root and shoot length decreased in response to increasing concentration of $\mathrm{NaCl}$; however, this decrease was more prominent in O. armena. No root and shoot growth was recorded at $\mathrm{NaCl}$ levels of $30 \mathrm{dS} \mathrm{m}$ (Table 2). The longest roots and shoots were obtained from O. viciifolia under all $\mathrm{NaCl}$ concentrations.

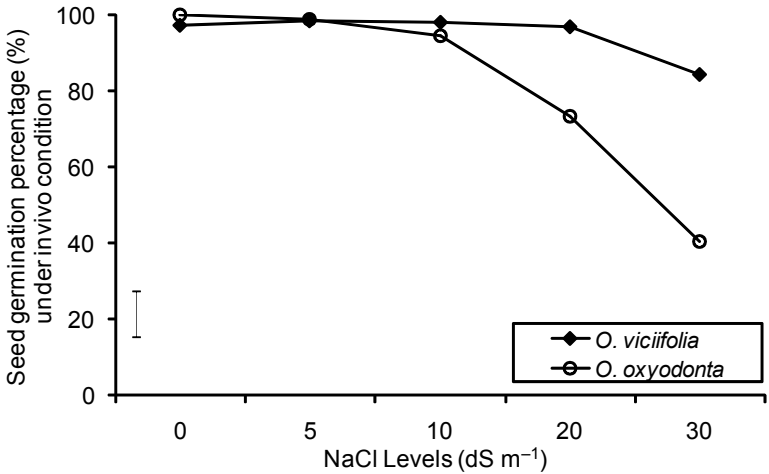

Figure 1 - Seed germination percentage of $O$. viciifolia $(\downarrow)$ and O. oxyodonta var. armena $(\mathrm{O})$ under in vivo condition. The bar represents LSD value which is 12.5 .

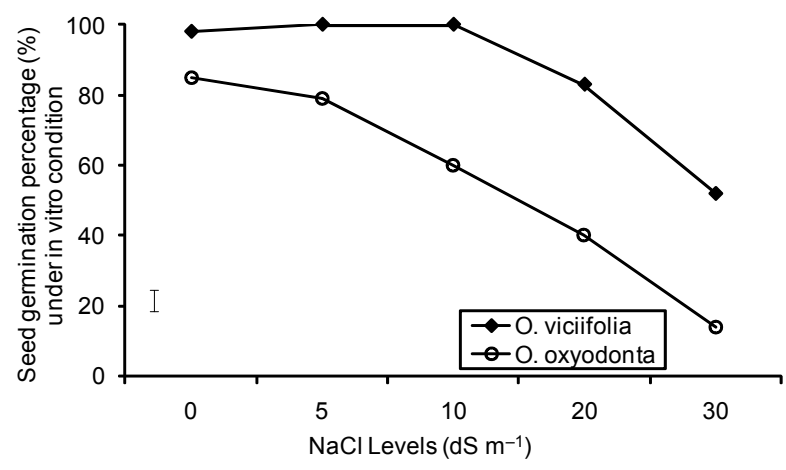

Figure 2 - Seed germination of O. viciifolia $(\checkmark)$ and O. oxyodonta var. armena $(\mathrm{O})$ under in vitro condition. The bar represents LSD value which is 5.98 .

Table 2 - Mean germination time (MGT), shoot length, root length, seedling fresh and dry weight and dry matter ratio of sainfoin species at various $\mathrm{NaCl}$ levels under in vitro conditions

\begin{tabular}{|c|c|c|c|c|c|c|c|}
\hline Variety & $\mathrm{NaCl}$ & MGT & Shoot length & Root length & Seedling fresh weight & Seedling dry weight & Dry matter \\
\hline \multirow{6}{*}{ O. viciifolia } & $\mathrm{dS} \mathrm{m}^{-1}$ & day & \multicolumn{2}{|c|}{ 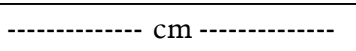 } & \multicolumn{2}{|c|}{ 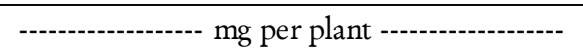 } & $\%$ \\
\hline & 0 & $3.01^{\mathrm{d}}$ & $4.65^{\mathrm{a}}$ & $5.60^{\mathrm{b}}$ & $368^{\mathrm{b}}$ & $42.8^{\mathrm{bc}}$ & $11.3^{\mathrm{de}}$ \\
\hline & 5 & $3.29^{\mathrm{d}}$ & $5.22^{\mathrm{a}}$ & $6.91^{\mathrm{a}}$ & $564^{a}$ & $64.5^{\mathrm{a}}$ & $11.3^{\text {de }}$ \\
\hline & 10 & $4.34^{\mathrm{c}}$ & $4.59^{\mathrm{a}}$ & $4.95^{\mathrm{bc}}$ & $513^{a}$ & $62.0^{\mathrm{ab}}$ & $11.0^{e}$ \\
\hline & 20 & $7.08^{\mathrm{a}}$ & $1.29^{\mathrm{e}}$ & $1.17^{\mathrm{e}}$ & $189^{c}$ & $30.0^{\mathrm{cd}}$ & $15.3^{\mathrm{bc}}$ \\
\hline & 30 & $-{ }^{e}$ & $-f$ & $-{ }^{f}$ & $-{ }^{\mathrm{e}}$ & $-{ }^{e}$ & $-f$ \\
\hline Mean & & 3.54 & 3.15 & 3.72 & 327 & 39.9 & 9.8 \\
\hline \multirow{5}{*}{$\begin{array}{l}\text { O. oxyodonta var. } \\
\text { armena }\end{array}$} & 0 & $5.05^{\mathrm{c}}$ & $2.66^{c}$ & $3.95^{\mathrm{cd}}$ & $334^{b}$ & $44.0^{\mathrm{bc}}$ & $13.5^{\text {cde }}$ \\
\hline & 5 & $4.64^{c}$ & $3.48^{\mathrm{b}}$ & $4.79^{\mathrm{bc}}$ & $193^{c}$ & $28.0^{\mathrm{cd}}$ & $14.5^{\mathrm{bcd}}$ \\
\hline & 10 & $6.07^{b}$ & $1.96^{\mathrm{d}}$ & $3.61^{\mathrm{d}}$ & $118^{\text {cd }}$ & $20.3^{d}$ & $17.3^{\mathrm{ab}}$ \\
\hline & 20 & $-{ }^{e}$ & $0.68^{e}$ & $1.25^{\mathrm{e}}$ & $75 d^{e}$ & $16.3^{\mathrm{cd}}$ & $19.5^{\mathrm{a}}$ \\
\hline & 30 & $-{ }^{e}$ & $-f$ & $-{ }_{-f}^{f}$ & $-{ }^{e}$ & $-\mathrm{e}$ & $-{ }_{-f}$ \\
\hline Mean & & 3.15 & 1.76 & 2.72 & 144 & 21.7 & 13.0 \\
\hline
\end{tabular}

Summary of ANOVA

\begin{tabular}{lllllll}
\hline Variety (A) & $\mathrm{ns}$ & $* * * * * * *$ & $* * *$ & $* *$ & $* *$ & $* *$ \\
$\mathrm{NaCl}(\mathrm{B})$ & $* *$ & $* *$ & $* *$ & $* *$ & $* *$ & $*$ \\
\hline $\mathrm{A} \times \mathrm{B}$ & $* *$ & $* *$ & $*$ & $* *$ & $* *$ \\
\hline
\end{tabular}

*significant at $p<0.05, * * p<0.01$ and ns: non-significant. Different letters at the same column show significant differences at 0.05 level. 
Compared to control, each increase in $\mathrm{NaCl}$ concentration resulted in remarkable decrease in fresh and dry seedling weights for the species. Although the species responded variable to different $\mathrm{NaCl}$ concentrations, the highest seedling fresh weight (564 mg per plant) and dry weight (64.4 mg per plant) were recorded at $5 \mathrm{dS} \mathrm{m}^{-1}$ for O. viciifolia. Depending on shoot and root length, seedling fresh weight fluctuated. In contrast, dry matter of the species was enhanced with increased $\mathrm{NaCl}$ except at $30 \mathrm{dS} \mathrm{m} \mathrm{m}^{-1} \mathrm{NaCl}$.

Pollen germination in control ranged from $83 \%$ for $O$. viciifolia to $96 \%$ for O. armena (Figure 3). Saline conditions induced a decrease in pollen germination. A very different response was detected between species at lower $\mathrm{NaCl}$ concentrations while none of the species were able to germinate at $30 \mathrm{dS} \mathrm{m}^{-1}$. Especially, $20 \mathrm{dS} \mathrm{m}^{-1}$ caused a detrimental effect on pollen germination.

Germination and seedling growth of the investigated sainfoin species were influenced by salt concentrations under in vivo and in vitro conditions. However, the responses of these species to salt concentration were different. Reduction in seed germination is in conformity with Khajeh-Hosseini et al. (2003), Murillo-Amador et al. (2002), who found that decreased germination was due to increased salinity. The results of this study are also in agreement with Prakash et al. (1998), Gadallah and Ramadan (1997), Gadallah (1996), Prakash et al. (1995) and Francois and Bernstein (1964), who emphasized that different varieties showed variable response against various salinity levels. Similarly, Hampson and Simpson (1990), Murillo-Amador et al. (2002), Okçu et al. (2005), Kaya et al. (2006), Karlidag et al. (2009) reported that $\mathrm{NaCl}$ had only adverse effect on germination by creating osmotic potential in the medium and caused delayed seed germination. There was a clear difference for germination and seedling growth under in vivo and in vitro conditions. Lower values were obtained from in vitro experiments; suggesting that the sucrose, MS mineral salts and agar and in in vitro conditions might have caused higher osmotic potential inhibiting germination and seedling growth of species than under in vivo conditions. Germination and seedling growth were reduced due to increased salt concentration with varying responses for species while $\mathrm{NaCl}$ affected germination of seeds by creating an external osmotic potential preventing water uptake

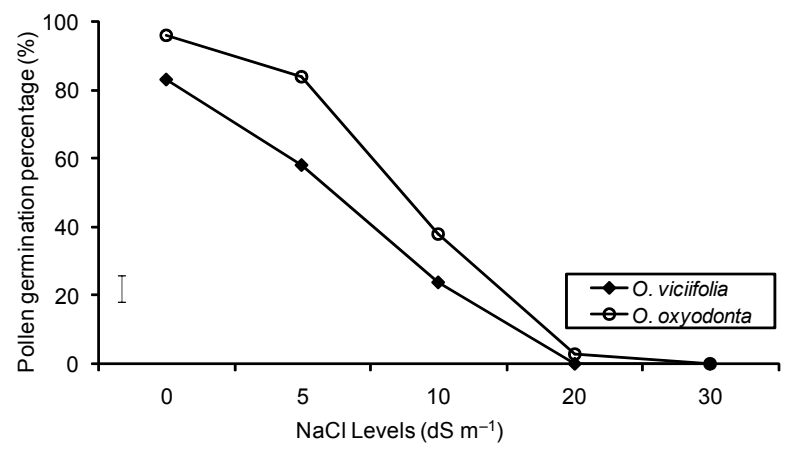

Figure 3 - Pollen germination of O. viciifolia $(\downarrow)$ and $O$. oxyodonta var. armena (O). The bar represents LSD value which is 7.02 .
(Pessarakli et al., 1991; Kaya et al., 2006). These results agree with Murillo-Amador et al. (2002) in cowpea and Okçu et al. (2005) in pea but should not be approved as a general rule because opposite results were recorded by Atak et al. (2006) who found reduced seedling growth under $\mathrm{NaCl}$ salinity. Pollen germination was also adversely affected by increasing $\mathrm{NaCl}$ concentration. $\mathrm{O}$. armena gave higher pollen germination at all $\mathrm{NaCl}$ levels; suggesting that there was no overlap in the response of seeds and pollen to $\mathrm{NaCl}$. Martinez-Pelle et al. (1995) found different responses with respect to pollen germination under various salinity stresses in pistacia species.

O. viciifolia gave higher seed germination and lower time to germinate under in vivo and in vitro conditions. However, the detrimental effect of $\mathrm{NaCl}$ on seedling growth was very evident in $\mathrm{O}$. armena because no shoot and root growth was recorded at $30 \mathrm{dS} \mathrm{m}^{-1}$. Furthermore, dry seedling weight and dry matter of the species enhanced with increased $\mathrm{NaCl}$ except at $30 \mathrm{dS} \mathrm{m}^{-1} \mathrm{NaCl}$ for O. armena. Similar findings have been reported in Bothriochloa persuta L., Dichanthium annulatum and Panicum antidotale under salinity (Akhtar and Hussain, 2008). The results are in line with the findings of Rehman et al. (2008) in wheat, Steppuhn et al. (2001) in canola, field bean, dry bean and drum wheat and $\mathrm{Li}$ (2008) in Limonium sinense, Sorghum sudanense and soybean.

In conclusion, critical period of crop plant to salinity generally occur on germination and seedling growth stages. The relative time of seed germination and seedling emergence of plants influences the degree of tolerance. Thus, the species or cultivars which rapidly germinate or emerge gain advantages for tolerance to $\mathrm{NaCl}$. $\mathrm{NaCl}$ caused an adverse effect on germination and seedling growth with delayed mean germination time in the species. Similar results were detected under in vivo and in vitro conditions while lower values were determined in in vitro. It seems that $O$. armena germinate and grow more slowly compared to $O$. viciifolia. Both sainfoin species could keep up with the salinity up to $10 \mathrm{dS} \mathrm{m}{ }^{-1}$ during seed germination and early growth stages, and $O$. viciifolia was more tolerant to $\mathrm{NaCl}$ compared to O. oxyodonta var. armena.

\section{References}

Açikgöz, E. 2001. Forage Crops. Uludag Universitesi Güçlendirme Vakfý Press, Bursa, Turkey. (in Turkish).

Akhtar, P.; Hussain, F. 2008. Salinity tolerance of three range grasses at germination and early growth stages. Pakistan Journal of Botany 40: 2437-2441.

Atak, M.; Kaya, M.D.; Kaya, G.; Çikili, Y.; Çiftçi, C.Y. 2006. Effects of $\mathrm{NaCl}$ on germination, seedling growth and water uptake of triticale. Turkish Journal of Agriculture and Forestry 30: 39-47.

Cavallarin, L.; Antoniazzi, S.; Borreani, G.; Tabacco, E. 2005. Effects of wilting and mechanical conditioning on proteolysis in sainfoin (Onobrychis viciifolia Scop) wilted herbage and silage. Journal of the Science of Food and Agriculture 85: 831-838.

Elçi, S. 2005. Legume and Grass Forage Crops. Ministry of Agricultural and Rural Affairs Press, Ankara, Turkey. (in Turkish).

Ellis, R.H.; Roberts, E.H. 1980. Towards a rational basis for testing seed quality. p. 605-635. In: Hebblethwaite, P.D., ed. Seed production. Butterworths, England. 
Francois, L.E.; Bernstein, L. 1964. Salt tolerance of safflower. Agronomy Journal 56: 38-40.

Gadallah, M.A.A. 1996. Abscisic acid, temperature and salinity interactions on growth and some mineral elements in Carthamus plants. Plant Growth Regulation 20: 225-236.

Gadallah, M.A.A.; Ramadan, T. 1997. Effects of zinc and salinity on growth and anatomical structure of Carthamus tinctorius L. Biologia Plantarum 39: 411-418.

Greub, L.J.; Drolsom, P.N.; Rohweder, D.A. 1985. Salt tolerance of grasses and legumes for roadside use. Agronomy Journal 77: 7680.

Hampson, C.R.; Simpson, G.M. 1990. Effect of temperature, salt and osmotic potential on early growth of wheat (Triticum aestivum L.). I. Germination. Canadian Journal of Botany 68: 524-528.

Imanparast, L.; Hassanpanah, D. 2009. Response of Onobrychis genotypes to PEG 10000 induced osmotic stress. Biotechnology 8: 368-369.

International Seed Testing Association [ISTA]. 2003. International rules for seed testing. Bassersdorf, Switzerland.

Karlidag, H.; Yildirim, E.; Turan, M. 2009. Salicylic acid ameliorates the adverse effect of salt stress on strawberry. Scientia Agricola 66: 180-187.

Kaya, M.D.; Ipek, A.; Ozturk, A. 2003. Effects of different soil salinity levels on germination and seedling growth of safflower (Carthamus tinctorius L.). Turkish Journal of Agriculture and Forestry 27: 221-227.

Kaya, M.D.; Okçu, G.; Atak, M.; Cikili, Y.; Kolsarici, O. 2006. Seed treatments to overcome salt and drought stress during germination in sunflower (Helianthus annuus L.). European Journal of Agronomy 24: 291-295.

Khajeh-Hosseini, M.; Powell, A.A.; Bingham, I.J. 2003. The interaction between salinity stress and seed vigour during germination of soybean seeds. Seed Science and Technology 31: 715-725.

Li, Y. 2008. Effect of salt stress on seed germination and seedling growth of three salinity plants. Pakistan Journal of Biological Science 11: 1268-1272.

Martinez-Pelle, E.; Herrero, M.; Aragues, R. 1995. Salt response of seeds and pollen of five pistacia species. Acta Horticulturae 419: 49-54.

Murashige, T.; Skoog, F. 1962. A revised medium for rapid growth and bioassay with tobacco tissue culture. Physiologia Plantarum 15: 473-497.
Murillo-Amador, B.; Lopez-Aguilar, R.; Kaya, C.; Larrinaga-Mayoral, J.; Flores-Hernandez, A. 2002. Comparative effects of $\mathrm{NaCl}$ and polyethylene glycol on germination, emergence and seedling growth of cowpea. Journal of Agronomy and Crop Science 188: 235-247.

Okçu, G.; Kaya, M.D.; Atak, M. 2005. Effects of salt and drought stresses on germination and seedling growth of pea (Pisum sativum L.). Turkish Journal of Agriculture and Forestry 29: 237-242.

Özaslan-Parlak, A.; Parlak, M. 2008. Effect of salinity in irrigation water on some plant development parameters of sainfoin (Onobrychis viciifolia Scop.) and soil salinity. Tarim Bilimleri Dergisi 14: 320-325.

Pessarakli, M. 1999. Handbook of Plant and Crop Stress. Marcel Decker, New York, NY, USA.

Pessarakli, M.; Tucker, T.C.; Nakabayaski, K. 1991. Growth response of barley and wheat to salt stress. Journal of Plant Nutrition 14: 331-340.

Prakash, M.; Babu, S.; Ramesh, M.; Thirumurugan, T.; Venkatesan, M.; Ganesan, J. 1998. Effects of $\mathrm{NaCl}$ priming on sesame seedling vigour under induced salinity conditions. Sesame and Safflower Newsletter, 13: 97-100.

Prakash, M.; Jagadeeswaran, G.; Murugan S.; Ganesan, J. 1995. Effects of seed treatment on germination and seedling attributes in sesame (Sesamum indicum L.). Sesame and Safflower Newsletter 10: 55-58.

Rehman, M.; Soomro, U.A.; Haq, M.Z.; Gul, S. 2008. Effects of $\mathrm{NaCl}$ salinity on wheat (Triticum aestivum L.) cultivars. World Journal of Agricultural Science 4: 398-403.

Sancak, C.; Coçu, S.; Khawar, K.M.; Ozcan, S. 2003. Abiotic factors affecting in vitro pollen grain germination in sainfoin (Onobrychis viciifolia Scop.). Pakistan Journal of Botany 35: 463-471.

Steppuhn, H.; Volkmar, K.M.; Miller, P.R. 2001. Comparing canola, field pea, dry bean and drum wheat crops grown in saline media. Crop Science 41: 1827-1833.

Received April 05, 2010

Accepted September 24, 2010 